\title{
EUROPEAN FINANCIAL NETWORK OF ISLAMIST TERRORISM
}

Keywords:

Islamist terrorism; Islamist terrorist organisations; terrorism financing; Europe; $E U ; U S$.

Author:

Dr. Jelena Vukoičić is an Associate Professor at the Faculty of Political Sciences of the Independent University Banja Luka, B\&H.

Correspondence: jelenavukoicic1@gmail.com

Field:

International relations

DOI:

10.5937/politeia0-17150

\section{Summary}

In this paper the author analyses one of the most important aspects of global Islamist terrorism on the territory of Europethe terrorism financing network. Although Europe has become on of the main targets of Islamist terrorists in recent years, its answer to the rising terrorism threat has, to this day, proven to be mild and ineffective. The same can be said regarding the European security officials' fight against the financial networks of terrorist organisations. While the US, after the attacks on New York and Washington in 2001, established the "Patriot Act", Europe did not follow through, which made it a perfect location for terrorists who were forced to withdraw their funds from America. The absence of a global and homogenous legislation comparable to the American "Patriot Act" can be partially explained by the fact that Europe does not possess the equivalent of a federal legislation because the degree of the political integration of the European Union members is much weaker than that of the American states. The lack of homogeneity of the European structures has allowed members of terrorist organisations to take advantage of gaps that exist in the local legislation of every country. Apart from the fact that the EU does not have a common set of anti-terrorism laws, its problem also lays in the fact that liberal-democratic European political elites place too much emphasis on the notion of human rights, which is, in fact, crippling their security forces and making it very hard for them to properly investigate individuals and organisations suspected of financing terrorist activities.

Paper received on:

12.04.2018.

Paper accepted for

publishing on:

05.10.2018. 


\section{INTRODUCTION}

Islamist terrorism, without any doubt, represents the biggest security threat in Europe today. Some EU countries have experienced the enormous rise of deadly terrorist attacks on a different scale in recent years, and it is an unfortunate, yet obvious fact that the terrorist threat will only rise in the future. In order to step up to the challenge and organise a successful fight against this form of political violence it is of extreme importance to analyse and understand all the sides and components of this phenomenon. Modern Islamist terrorism is a very complex form of political violence, and there are many different aspects of it that need to be studied and understood in order to effectively tackle this huge security threat. One of the most important aspects of terrorism is its financial network, without which no terrorist organisation would be able to survive. In order to be sustainable every terrorist group must necessarily be able to first build and then maintain the financial infrastructure that is used to fund its logistics and, ultimately, to plan and execute the terrorist attacks.

Islamist terrorist groups vary widely in size, ranging from large, state-like organisations, such as Islamic state, to small, decentralised networks that are sometimes composed of a few or even one individual inspired by radical ideology. Terrorists' financing requirements reflect this diversity, varying greatly between organisations. However, as already noted, what is certain is that no terrorist group can function without a stable cash flow; financing is required to meet broad organisational costs of developing and maintaining a terrorist organisation, to create an enabling environment necessary to sustain various organisations' activities, and, finally, to fund specific terrorist operations. (Vukoičić, 2016: 512; Ryder, 2015).

Terrorism financing is a complex phenomenon itself considering the fact that the financial networks of terrorist organisations are, in most cases, wide and diverse. Terrorism is financed through both legitimate and illegitimate activities, which together construct a wide and complex network that is hard to penetrate. On the one hand, a significant number of religious institutions, such as Islamic charities, mosques, Islamic banks, educational and cultural centres operate as fronts, and, on the other hand, money is collected through a wide range of highly profitable criminal activities from petty crime to organised crime, narcotics trade, people smuggling, arms dealing, etc (Ionescy, 2015; Tierney 2017; Keatinge, 2014).

Although some intelligence agencies, especially in the Western world, have put in a lot of effort in the last few decades to cut the cash flow of terrorist money, the Islamist financial network remains a strong and solid structure, surrounded by considerable mystery and intrigue. Part of the problem lies in the Islamists' ability to use globalisation to their advantage; the other part lies in the inability of governments to carry out, under the aegis of an international organisation like the United Nations, a global policy that seeks to prevent the financing of terrorism. Some countries, such as the United States, have adopted special and strict anti-terrorism laws and regulations. However, these measures have not resulted in the creation of a similar legislation in the rest of the world, even in its Western part. Europe, in particular, has not been successful in preventing the financing of terrorist organisations and money laundering on its territory. When compared 
to the United States, the European answer has been, up until now, weak, partial and, finally, hardly effective. One of the consequences of this, unfortunately, has been the rising number of terrorist attacks in recent years, which have shown the vulnerability of the Old continent. In a globalised world, anti-terrorist financing laws and measures should be global in order to be successful. In the case of Europe this would, first and foremost, mean that the EU, as a political union, would have to adopt a common set of strict and effective anti-terrorism measures and anti-terrorism financing laws.

\section{EUROPEAN ISLAMIC FINANCIAL NETWORK}

As already noted, Islamist terrorism is financed through many different, legitimate and illegitimate, activities. The connection between terrorism and crime is well known and well documented. Most terrorist organisations go hand in hand with intense criminal activity including smuggling, drug dealing, weapon trafficking, human trafficking, kidnapping and extortion. On the other hand, large portions of terrorists' funds are derived from legitimate activities, including money from various business ventures, donations, welfare payments, etc. However, a particularly sensitive issue, when it comes to terrorism financing in Europe, is represented by various Islamic institutions and organisations that deal with fund raising, because of the reluctance on the part of European security forces to rigorously scrutinise their activities. European, liberal-democratic sensitivity and a blind desire to respect the very notion of, so called, human rights is very well known and widely exploited by terrorists and their financial supporters who are often masking their criminal and terrorist activities with religion, and are, more often than not, getting away with it. Many Islamic institutions, because of their 'sanctity' have simply turned to places that serve no other purpose but to launder money from the variety of criminal activities and to channel these and other funds to various, anonymous beneficiaries spreading Islamist ideology and organising terrorist attacks all over Europe and the world. Another paradox regarding Islamic charities, Islamic cultural and educational centres, mosques, etc. is the fact that many of these are actually receiving government funds and subsidies which clearly points out another absurdity of the European liberal democracies - In its desperate need to somehow please 'angry' and 'alienated' local Muslims, liberal-democratic European political elites are actually taking an active part in the terror attacks on their own citizens. To sum up, political correctness (PC) throughout Europe has been of greater value to the political, liberal-democratic elites of the EU and the terrorists, than the protection of Europe's citizenry.

\section{MOSQUES' AND ISLAMIC CHARITIES' ROLE IN TERRORISM FINANCING}

In the last couple of decades Islamist terrorist organisations, operating in Europe, have penetrated a huge number of mosques, Islamic cultural and educational centres, and NGOs engaged in the promotion of human rights, health and relief projects. The network of mosques and Islamic centres in Europe has been so successful in the process of recruiting and fundraising that many have now become hotbeds of potential terror fighters, who have been fed an explosive mixture of religion and political ideology. As Loretta Napoleoni points 
out, "the mosque network is the ideological partner of the terror financial network; it complements it and it is as complex and comprehensive a web as its monetary counterpart” (Napoleoni, 2004: 172). Napoleoni emphasises that the mosque network "continues to be the main vehicle through which Islamist organisations, countries, stateshells, armed groups and their sponsors link up and do business with each other" (Ibid). European mosques are often described, by the counterterrorism officials, as havens of tranquility that allow for the collection of funds and the planning of terrorist acts (Mackay, 2004)

Beside mosques, the other key part of the Islamic institutions' terror funding network are Islamic humanitarian organisations, that is, Islamic charities. It is a well-established fact that most terrorist organisations have traditionally relied on Islamic charities for some of their funding (Meotti, 2017) Islamic charities constitute an important part of Muslim tradition and Sharia law as there is a recognised religious duty in the Islamic world to provide a set portion of ones earnings or assets for religious or charitable purposes (Zakat), and otherwise to support charitable works through voluntary deeds or contributions (Sadaqah). One of the most convenient ways to fulfill this religious obligation is by giving through Islamic charities "whose funds have been one of the most dominant aspects of Islamic economies" (Burr \& Collins, 2006:23). The primary function of Islamic charities is to provide basic goods and services to Muslim communities in a manner deemed consistent with the values and teachings of Islam. This includes medical services through local clinics and hospitals, schools, universities and colleges, orphanages, vocational training centres, subsidies for poor families, and other grassroots activities. Islamic charities also collect donations to help Muslims outside their own country and outside of countries with Muslim majorities (Vukoičić, 2016:512).

Islamic charities are well known for their lack of transparency when it comes to financial transactions. Donations in large measure remain anonymous, and the same goes for final beneficiaries. Quite naturally, the opaque financial and operating structure of these organisations provides an ideal environment for exploitation by terrorist groups. As Loretta Napoleoni notes, "humanitarian aid is allocated by charitable organisations to a range of projects, from the construction of mosques and madaris to the purchase of arms and the sponsorship of terror attacks. The combination of humanitarian aid and illegal activity is typical of Islamic charities linked to terror groups" (Napoleoni, 2004:224).

Islamic charitable organisations located in Europe are attractive targets for terrorist organisations because of the reluctance on the part of many European countries to rigorously scrutinise their activities. Unable to conduct proper investigations and with limited information, authorities are put in the awkward position of being pressured to determine whether money collected for a particular legitimate cause is actually used for that purpose or not (Vukoičić \& Rodić, 2016:186).

In order to deal with this complex issue, and detach Islamic charities, mosques and other religious institutions not involved in terrorism financing from those funding terrorist organisations, European security institutions would have to approach the problem from a united front, in a serious and uncompromising way. Unfortunately, this is not the case. On the contrary, there 
are many problems and weaknesses that can be detected when observing European governments' measures against Islamic institutions involved in the financing of terrorism. To date, European governments have relied on an array of strategies to cope with this security threat. These strategies "range from monitoring or engaging with Islamic charities, to regarding their registration through special charity commissions, to shutting them down altogether. This mosaic of national responses has prevented the European Union from developing a comprehensive approach, which poses two problems. First, the lack of an effective EU strategy or policy vis-à-vis Islamic charities has permitted groups that have been shut down in one country to move to a less-regulated state and continue their work virtually unencumbered. Second, regulatory discrepancies among EU member states have created tension with the US, which tends to take a much harder line on charities" (Smith \& Filipiak, 2007:82).

Some of the countries have used intense monitoring and surveillance to pursue groups suspected of having links to terrorist activity. Other European countries have tried partnering with Islamic charities with the hope that engagement inspires transparency and keeps the charities accountable. Finally, a number of European countries have chosen to ignore the problem of radical Islamic institutions altogether.

Although some would expect the European Union to, at least, have a common set of anti-terrorism measures, unfortunately, that is not the case. As Julianne Smith and Natalia Filipiak emphasise, "the EU's approach to Islamic charities is complicated by the contrasting domestic political contexts in which Muslim communities, and by default Islamic charities, exist throughout
Europe. From secularism, to multiculturalism, to full-fledged integration, each member state takes its own individual approach toward its immigrant community and the nonprofit sector more broadly. It should be no surprise that, against a back drop of the wide array of domestic and foreign priorities that exist across Europe, the EU faces a difficulty in mastering the political will to create consensus and common policies on the issue of regulating and monitoring Islamic charities" (Smith \& Filipiak, 2007:87). Although many European countries have restored old anti-terrorism laws and introduced new ones in order to try and address the rising terrorism threat, not all European policymakers have been willing to put these new legal frameworks into practice: "Indeed, they argue for discreet investigations that will not upset the sometimes delicate politics associated with their large - and often alienated and marginalised - Muslim populations" (Smith \& Filipiak, 2007:86).

As can be seen, the reluctance of some European liberal-democratic governments to effectively tackle the issue of Islamic charities who sponsor terrorism to a large extent lays in the very name and nature of these organisations, that is the fact that they are both Islamic and Charitable. The desire to be politically correct, especially when dealing with the sensitive Muslim minority issues, and to respect ideas and laws dealing with human rights issues, creates a great obstacle in the fight against terrorism and its financial network. On the other hand, Islamic charities, mosques and similar institutions that sponsor terrorism take full advantage of the protection guaranteed to them by democratic European laws, as well as 'political and ethnic correctness', which is crippling European security forces, 
preventing them from being more efficient in the fight against this global security threat (Vukoičić, 2016:517). In recent years Islamist terrorist organisations have taken full advantage of the lack of oversight on behalf of European governments to penetrate the existing and open their own charities, and to obtain funds through donations at mosques and various Islamic centres. Funds raised or allocated by or for terrorists are mixed, maintained and transferred along with funds designated for legitimate relief and developmental activities. Since proper investigations are rarely conducted, the funds' ultimate use to support terrorist activities can only become known when the money is transferred or diverted to specific terror groups-related recipients.

\section{THE TERRORIST TIES OF THE ISLAMIC BANKS' NETWORK}

One of the most important financial network of terrorist organisations in Europe is the Islamic banking system, a global and complex financial structure governed by Islamic, that is Sharia Law. The organisation of a typical Islamic bank provides insights into how the system can be misused for financing of terrorism. The Islamic bank is obliged to have a control committee called the Sharia Committee (also known as the Islamic Legal Control Committee for the Preservation of Islamic Law), which acts as a religious and accounting standards committee, making decisions about what financial instruments are able to be used by the bank under Sharia Law. The majority of the members of the committee are Islamic clerics, and the committee has wide-ranging powers over the banks activities, investments and operations, including its dealings in all different accounts (Acharya, 2009:72-74).

One of the key accounts relevant to the issue of terrorism financing is the Mudaraba account that the customer is obliged, under Sharia Law, to open with the bank to keep a part of the proceeds from investment for charity in compliance with Islamic obligations. Depending on the nature of the account, the investor is free to choose the charitable deed that he wishes to finance (a free Mudaraba account), or surrenders this responsibility to the Sharia Committee (a restricted Mudaraba account); the most important task of the committee in the latter case is to decide on the amount of zakat (alms or donation) and where this amount should go. Given the generally lax oversight of Islamic banks and financial institutions in Europe, and the lack of general understanding of the operation of the Sharia Committees within Western-based Sharia-compliant financing structures, the potential for abuse, particularly in the context of diversion of the zakat to Islamic charities which channel their contributions to Islamic terrorist groups, is significant (Acharya, 2009:73).

The financial network of Islamic banks cooperates closely with the international networks of correspondent and offshore banks. In the formal financial sector, it is well known that the weakest link, from a supervision, security and law enforcement perspective, is the international network of correspondent banks. Correspondent banking refers to the global network of relationships between major, brand name banks and smaller banks in foreign jurisdictions (including, but not limited to, tax havens). Not surprisingly, this difficulty to police the network of correspondent banking has been heavily used by terrorists in the financing 
of their operations, and represents a key element of the terrorist financial infrastructure. The main channels through which the sponsors of terrorism transfer money in Europe are offshore accounts and banks recorded in tax havens without having a real existence, or rather, shell banks. Generally speaking, offshore banks form the part of the international financial system, which has historically been largely beyond the reach of the law and tax authorities of Western jurisdictions. Offshore banking and offshore financial centres (OFCs) have the express aim of attracting capital from other countries, which they reward with more lenient rules than it would encounter at home, with the benefits to the host nation being revenues generated by charging fees for the issuance of various licenses and documents, such as articles of incorporation or licenses for banking services and mutual and hedge funds (Naim, 2005: 140141) As such, their more lenient rules, lax supervision and general opacity to regulatory scrutiny make them perfectly suited for performing their role as part of the day to day financial infrastructure of Islamist terrorism, through facilitating fund transfers through the international banking system, while at the same time effectively concealing both the true identities of the real owners and the actual purpose of the funds transfers (Ehrenfeld, 2005:13)

The "Patriot Act" adopted in the United States after September 11th has forbidden American banks and foreign banks registered in the United States to trade with such banking structures registered in tax havens. However, a similar legislation does not exist in Europe, which has largely contributed to the Old Continent becoming a safe haven for terrorist financial transfers. Apart from the lack of a common legislation that would make it much easier to control the money trail in suspicious transactions, another problem with the control of the Islamic banks that are funding terror on European soil stems from the same source that is undermining the overall struggle against Islamist terrorism and its financial network on the territory of the Old continent - political sensitivity regarding minority (that is, Muslim) issues. European authorities are often hesitant when it comes to properly investigating Islamic banks, just as they are when it comes to Islamic charities, cultural centres, mosques, etc. Unless there is concrete evidence that a certain bank is funding terrorism, security officials usually avoid a direct confrontation with a suspected institution for fear of 'insulting and upsetting' the local Muslim population. Islamic extremists and terrorists are, obviously, very much aware of this weakness of European authorities and have been extremely successful in exploiting it so far, which can be observed in the rising number of deadly terrorist attacks in recent years.

\section{INEFFICIENCIES OF THE EUROPEAN ANTI-TERRORIST POLICIES}

The ability of terrorist organisations to create and maintain stable financial networks on the international level has been encouraged by the inability of the United States, the European Union, and international financial institutions to adopt a common set of anti-terrorist polices, including similar regulatory frameworks, scope of groups targeted, and responses and penalties. This lack of unity on behalf of international actors has encouraged jurisdiction shopping by terrorists and their financiers (Vukoičić \& Rodić, 2016:190). Since the US counter-terrorism legislation became 
tougher than Europe's post 9/11, some Islamist terrorist organisations have transferred their logistics to a less stringent jurisdiction, that is, the countries of the EU.

According to Loretta Napoleoni, "while the US adopted a zero-tolerance approach $v i s$ - $-v i s$ charities that are somehow linked to terror organisations, the European Union protected organisations which perform humanitarian work and worried about affecting their valuable activity" (Napoleoni, 2004:284). However, the biggest advantage Europe has offered terror finances is the absence of a global and homogenous legislation similar to the American "Patriot Act"(Ibid.). The inability of the EU to adopt a common set of counterterrorism laws can be partially explained by the fact that the degree of political integration of the European Union countries is much weaker than that of the American states. Since the EU does not possess the equivalent of a federal legislation, it can only decree directives and codes of conduct that the individual member states can later choose to apply or not apply. These sorts of documents, however, cannot act as a substitution to a uniform and rigorous legislation such as the "Patriot Act", or a similar legislation exclusively regarding terrorist activities. The actions undertaken by the EU seem more like "good intentions" rather than the ability to act together against this huge security threat. Mainly for this reason it has been easy for the Islamist terrorist groups to take advantage of the different approaches between Europe and the United States (Ibid).

Apart from the lack of a unified set of antiterrorism laws, there are, actually, other numerous limits of the EU financial counter-terrorism policies. A good example of the lack of European unity on the sensitive and extremely important question of security can be seen in the example of one of the key EU institutions that should fight against terrorism - Europol. Although Europol, which does not have powers of arrest, has attained significant support from member states to facilitate the exchange of information, its operational role is limited. This, in turn, results in a restricted role and less influence for the EU institutions. In 2014, Europol launched the Focal Point Travellers scheme, which is designed to hold information about individuals suspected of traveling across borders to participate in terrorist activities. The intention was to help European countries by collecting, analysing and sharing information on the recruitment and movements of outgoing and returning terrorists. But Europol never received across-the-board support, with only half of the EU's 28 members registering their respective nationals on the Europol Information System database by the day of the Paris attacks (Gohel, 2016).

Apart from the apparent unwillingness, on behalf on some countries, to share the intelligence information, the EU also has the problem of a more practical nature, that is the problem based on a huge difference in the available financial resources of member states. Less-affluent countries do not have the resources to identify, track and follow militants over a long period of time. Countries such as France and the U.K. are devoting millions of dollars to build up their counterterrorism infrastructure, but smaller, poorer countries are still struggling to finance the struggle against terrorists. Belgium, for example, does not have the capacity or intelligence training to implement any meaningful system that would have an impact domestically, let alone participate in a Europe-wide information sharing. 
The ineffective anti-terrorism measures, lack of unity and other problems that the $\mathrm{EU}$ is facing in its fight against terrorism have, ever since the attacks on New York and Washington, transformed Europe into the new operating and financial base of Islamist terrorism in the West. While before September $11^{\text {th }}$ the Old continent was less interesting than the United States regarding money laundering for terrorist operations, since that period Europe has become the world centre for this activity. After the adoption of the "Patriot act" in the US, Islamist terrorist groups have simply transferred their money laundering activities from the New to the Old Continent. In the same way, the various sponsors of terrorism have withdrawn their capital from the American market and reinvested in Europe. The European position as the new centre of terrorism financing has also been influenced by the inability of the global community, mainly the West and the Muslim world, to enact the United Nations' recommendations in order to fight the financing of terrorism. The unilateral policies conducted by some large countries, especially the United States, do nothing to engage the others, in particular Muslim states, some of which are well known sponsors of terrorism, to submit to international decisions. Without a global antiterrorist strategy, the United States' unilateral approach has had the consequence of transforming Europe into a new front for the war against the West declared by Islamism. Unfortunately, at this time, the EU is faced with a biggest economic and political crisis since its foundation, and it is uncertain when and/or if this crisis, which begun in 2008, will actually end. The mounting problems and issues between EU members, quite naturally, cannot help the issue of the fight against terrorism and terrorism financing becoming more effective. It is quite unclear as to whether the European Union is actually capable of creating a united front against this extremely dangerous form of political violence.

\section{CONCLUSION}

Although some European countries have seen a dramatic surge in the number of Islamist terrorist attacks in recent years, the Old continents' answer to the rising terrorism threat has, so far, proven to be mild, chaotic and ineffective. The same can be said regarding the European security officials' fight against the financial networks of terrorist organisations. While the US, after the attacks on New York and Washington in 2001, established the "Patriot Act", Europe did not follow through, which made it a perfect location for terrorists who were forced to withdraw their funds from America.

There are a number of reasons as to why the European fight against Islamist terrorism and the financing of terrorism have so far proven to be ineffective:

1. The European Union does not possess a common set of laws against terrorism financing or, in fact, any common set of measures that would deal with this security issue on the territory of all the countries that are a part of this political and economic union.

2. There is an apparent unwillingness of EU member states to share intelligence and exchange information on security issues within the EU framework, including through institutions such as Europol. Instead, some nations opt for bilateral agreements to share intelligence outside EU structures.

3. EU countries do not have the same capabilities when it comes to investing money 
in the fight against terrorism and terrorism financing. While some large and affluent countries are devoting millions of dollars to build up their counterterrorism infrastructure, smaller, poorer countries are struggling to find resources to support the fight against terrorists and terror suspects.

4. The liberal-democratic European political elites put much emphasis on the notion of human rights, which in essence prevents security officials from successfully fighting terrorism. The protection and respect of human rights, when taken to the extreme (which often happens in liberal Europe) actually facilitate terrorists' operation and protect their 'rights' instead of the rights and lives of the majority of European citizens.

5. There is a resistance on behalf of some European politicians to follow in the steps of United States when it comes to anti-terrorism laws and measures. They fear to appear like puppets of the White House by accepting to apply laws as strict as those passed on the other side of the Atlantic. The rejection of the "American style" fight against terrorism and terrorism financing is mostly related to the very notion of human rights, as it is understood in the European liberal-democratic context.

6. Last but not least, the EU has been in a profound, economic and political crisis, for almost a decade now. The crisis seems to be deepening at this time, so it is unclear as to how that would affect any attempts on behalf of the European Union members to fight unitedly against terrorism and its financial network.

Islamist terrorism is probably the biggest security challenge the global community is faced with in this present time. It is a complex and unpredictable form of political violence that has to be dealt with globally and in an organised way if positive results are to be expected. In the ideal situation, there would be a global set of measures against terrorism and terrorism financing; however, this 'ideal' solution is a far cry from reality. On the other hand, what could be achieved, if there was enough political will on behalf of all the actors, is a united front in the fight against Islamist terrorism and its financial network in the Western world which has, so far, been one of the main targets of Islamist terrorists. Unfortunately, the present situation does not look very promising regarding this matter because of the differences in the legislation between the United States and the European Union. While the US is extremely rigorous in relation to the organisations suspected of financially supporting armed Islamic movements, the Europeans do not stop insisting on the opportunity to distinguish the organisations infiltrated by terrorists from those that carry out a real humanitarian purpose, for fear of influencing the legitimate activities of the latter. The majority of the European liberal-democratic political elites have, so far, proven to be weak, indecisive and scared that the firm action against terrorist suspects and terrorist supporters, including individuals and organisations suspected of financing terror activities, would ultimately result in the further alienation and radicalisation of European Muslims. Whether that would actually happen or not is not a part of this analysis, but any hesitation to take a firm stand against the biggest security threat in the Old continent can only encourage existing and would-be terrorists and make matters worse. 
If the European Union wants to be taken seriously, both by the majority of its peaceful citizens and by those who are dreaming of its physical destruction, it has to act seriously, and it has to start doing so in the very near future. Islamist terrorists have a long term goal of destabilising (and ultimately destroying) Europe by attacking it whenever and wherever possible, which is exactly what they have been doing, rather successfully, for the past few years. At this moment, the Old continent is looking like a very easy target for the huge, driven, well-organised and very well financed network of Islamist terrorists. One thing is for sure - Unless the EU adopts a common set of strict counterterrorism laws, including the effective measures against terrorism financing, and unless it allows the security officials to properly investigate individuals and organisations suspected of terrorist and criminal activities, Europe will continue, more and more so, to be an easy target for and a playground of Islamist terrorists in the future.

\section{REFERENCES}

Acharya, A. (2009). Targeting Terrorist Financing: international cooperation and new regimes. New York, NY: Routledge.

Burr, J. M. \& and Collins O. R. (2006). Alms for Jihad: Charity and Terrorism in the Islamic World. Cambridge: Cambridge University Press.

Ehrenfeld, R. (2005). Funding Evil - How terrorism is financed - and how to stop it. Chicago. IL: Bonus Books.
Gohel, S. (2016). The challenges of EU counter-terrorism cooperation. Security Europe. http://europesworld.org/2016/12/12/challenges-eu-counter-terrorism-cooperation/\#. WNaosxiZO8U.

Ionesku, I. (2015). Financing terrorism: From offshore companies to the charity paradox. SEA - Practical Application of Science. Vol. 3. Issue 2 (8).

Keatinge, T. (2014). Finances of the Jihad: How extremists groups raise money. BBC. http://www.bbc.com/news/ world-middle-east-30393832.

Levitt, M. (2002). The Political Economy of Middle East Terrorism., Middle East Review of International Affairs 6:4..

Mackay, N. (2004). Was it ETA or al Qaeda? The confusion over who was behind the Madrid bombing obscures intelligence predictions of an enhanced terror threat. The Sunday Herald.

Meotti, G. (2017). Europe funds its own bloodbath, Arutz Sheva,. israelnationalnews.com.

Naim, M. (2005). Illicit-how smugglers, traffickers, and copycats are highjacking the global economy. New York, NY: Anchor Books, Random House.

Napoleoni, L. (2004). Terror Inc: Tracing the Money behind Global Terrorism, London: Penguin books.

Ryder, N. (2015). The Financial War on Terrorism - A review of counter-terrorist strategies since 2001. London and New York: Routhledge. 
Smith, J. \& Filipiak, N. (2007). Islamic charities in Europe, in: J. B. Alterman \& K. Von Hippel (eds.), Understanding Islamic Charities. Washington D.C.: Centre for Strategic and International Studies.

Tierney, M. (2017). Well funded and dangerous: assessing the Islamic State's financing operations. Journal of Money Laundering Control, Vol. 20, Issue: 2.

Vukoičić, J. (2016). Economics of Political Violence: The Role of Islamic Charities in the Global Terrorism Financing. Archibald Reis Days Conference Proceedings, Vol 2, Belgrade.

Vukoičić, J. \& Rodić, G. (2016). Financing of Terrorism in Europe. Evropske integracije: Pravda, sloboda i bezbednost - Zbornik radova, Tom 2 . Tara. 


\section{ЕВРОПСКА ФИНАНСИЈСКА МРЕЖА ИСЛАМИСТИЧКОГ ТЕРОРИЗМА}

Кључне ријечи:

Исламистички

тероризам; исламистичке терористичке организаиије; финансиране тероризма; Европа; ЕУ; САД.

Ауторка:

Др Јелена Вукоччић је ванредни професор на Факултету политичких наука Независног универзитета Бања Лука, БиX.

Коресподенција: jelenavukoicic1@gmail.com

Област:

Међународни односи

DOI:

10.5937/politeia0-17150

Датум пријема чланка: 12.04.2018.

Датум прихватања чланка за објављивање:

05.10.2018.

\section{Сажетак}

У овом раду аутор анализира један од најзначајнијих аспеката глобалног исламистичког тероризма на територији Европе - терористичку финансијску мрежу. Иако је Европа протеклих година постала једна од главних мета исламистичких терориста, нен одговор на растућу претюу тероризма показао се као слаб и неебикасан. Исто се може рећи и за борбу европских безбедносних снага против финансијских мрежа терористичких организаиија. Док су Сједиюене Државе, након напада на Њујорк и Вашингтон 2001. године, донеле "Патриотски декрет", Европа није урадила ништа слично, ито је од не направило савршену локацију за терористе који су били принуђени да повуку своја средства из Америке. Непостојағе глобалног и хармонизованог сета закона попут "Патриотског декрета" може се делимично објаснити чиненииом да Европа нема еквивалент америчком федералном законодавству због тога што је ниво политичке интеграције чланица Европске Уније много нижи од оног који поседују Америчке државе. Непостојане хомогенитета у европским структурама омогућило је члановима терористичких организаиија да искористе предност пукотина у законским системима ЕУ држава. Поред чиюенице да ЕУ нема јединствени сет антитерористичких закона, проблем такође лежи у чиюеници да европске либерално-демократске политичке елите ставлају превелико тежиште на концепт тьдских права што, суштински, онемогућава рад нихових сопственох безбедносних снага и отежава им спровођене истрага над појединиима и организачијама осумғиченим за финансиране терористичких активности. 